\title{
ANALISIS RASIO LIKUIDITAS, SOLVABILITAS DAN PROFITABILITAS PADA BANK NAGARI PUSAT
}

\author{
Asyfa Zahra Ramadanti, Elva Dona \\ Akademi Keuangan dan Perbankan "Pembangunan" Padang \\ Asyifazahrar01@gmail.com
}

\begin{abstract}
The purpose of this study is to study how the financial ratios and the development of the Central Nagari Bank by ussing liquidity, solvability and profitability ratios. The research method used is and descriptive data analysis methods. The type of data used is secondary data obtained from the Financial Services Authority report and Bank Nagari publication reports for the 2017-2019 period. The results of this study indicate that the bank's liquidity ratio is stated in a healthy condition. The solvability ratio also shows that the bank is in a healthy condition because the bank can pay its long-term loans and obligations. In the profitability ratio, the bank shows that according to BI standards it is still in the good category.
\end{abstract}

Keywords : Liquidity, Solvability, and Profitability

\section{PENDAHULUAN}

Pada era globalisasi saat ini peranan bank sangat penting bagi masyarakat Indonesia, karena pada dasarnya bank bertujuan untuk menunjang perekonomian masyarakat di pusat maupun di daerah dalam rangka meningkatkan kesejahteraan masyarakat. Bank merupakan salah satu lembaga keuangan yang mempunyai peranan penting dalam perekonomian suatu negara. Bank dalam pasal 1 ayat (2) UU No.10 Tahun 1998 tentang perubahan UU No.7 Tahun 1992 tentang perbankan, menurut (Hutabarat, 2013) pengertian Bank adalah badan usaha yang menghimpun dana dari masyarakat dalam bentuk simpanan dan menyalurkannya kepada masyarakat dalam bentuk kredit atau bentuk-bentuk lainnya dalam rangka meningkatkan taraf hidup rakyat banyak.

Berdasarkan Undang-Undang No.10 tahun 1998 tentang perbankan, menurut jenisnya bank terdiri dari Bank Umum dan Bank Perkreditan Rakyat (BPR). Bank umum (Albahi, 2015) adalah bank yang melaksanakan kegiatan usaha secara konvensional dan/atau berdasarkan prinsip syariah yang dalam kegiatannya memberikan jasa dalam lalulintas pembayaran. Sifat jasa yang diberikan adalah umum, dalam arti dapat memberikan seluruh jasa perbankan yang ada.

Laporan Keuangan merupakan data-data keuangan yang sifatnya kuantitatif. Menurut (Sepang et al., 2019) laporan keuangan menggambarkan kondisi keuangan dan hasil usaha suatu perusahaan pada saat tertentu atau jangka waktu tertentu. Adapun jenis laporan keuangan yang lazim dikenal adalah neraca, laporan laba rugi dan laporan perubahan modal.

Dalam laporan neraca tersebut kita dapat mengetahui kekayaan atau asset yang perusahaan miliki (disisi aktiva) dan disisi pasiva dapat diketahui dari mana 
dana-dana untuk membiayai aktiva (dari modal sendiri atau hutang) tersebut kita peroleh. Laporan laba rugi memberikan informasi mengenai berapa jumlah penghasilan atau pendapatan yang diperoleh serta berapa biaya yang dikeluarkan perusahaan pada periode tertentu. Laporan ini juga memperlihatkan pendapatan bersih atau kerugian bersih sebagai hasil dari operasi perusahaan selama periode tertentu. Sedangkan laporan perubahaan modal memberikan gambaran mengenai perubahan modal akibat dari aktivitas perusahaan seperti perusahaan mengalami laba atau rugi serta akibat dari pengambilan uang pribadi oleh pemilik perusahaan.

Selain manajemen yang baik, dalam suatu perusahaan juga memerlukan sebuah analisis terhadap laporan keuangan untuk mengetahui kemampuan perusahaan dalam mengatasi masalah-masalah keuangan perusahaan serta mengambil keputusan yang cepat dan tepat. Melalui analisis rasio ini, manajemen dapat mengetahui posisi keuangan, kinerja keuangan dan kekuatan keuangan (financial strength) yang dimiliki perusahaan. Analisis rasio laporan keuangan yang lazim digunakan (Yusra, 2016) adalah analisis rasio likuiditas, analisis rasio leverage atau solvabilitas dan analisis rasio profitabilitas. Rasio-rasio ini akan memperkuat kekuatan bank tersebut dalam pembiayaan dan juga menangani permasalahan yang dihadapi oleh bank, karena dengan adanya rasio-rasio ini bank bisa mengetahui sehat atau tidaknya suatu bank.

Dalam hal pelaporan keuangan, Bank Nagari sudah menggunakan sistem pencatatan keuangan yang canggih dengan menggunakan computer untuk mengetahui posisi keuangannya setiap akhir tahun tetapi belum tentu akurat. Maka dari itu kita perlu melakukan analisis rasio dalam menilai kinerja keuangan terhadap jasa yang telah dilakukan. Menurut (Utomo, 2008) analisis laporan keuangan Bank Nagari dapat dilakukan melalui aspek likuiditas, solvabilitas dan profitabilitas dengan menggunakan laporan keuangan (neraca dan laporan laba/rugi) dari tahun 2017 sampai dengan tahun 2019.

Berdasarkan uraian latar belakang di atas, mendorong penulis melakukan penelitian dengan judul: "Analisis Rasio Likuiditas, Solvabilitas, Dan Profitabilitas Pada Bank Nagari Pusat".

\section{METODE PENELITIAN}

Dalam pengumpulan data untuk melakukan penelitian ini digunakan metode sebagai berikut :

1. Metode pengumpulan data

a. Dokumentasi

Pengumpulan data dilakukan dengan cara wawancara langsung dengan responden sesuai dengan tujuan penelitian.

b. Studi perpustakaan (Library research)

Penelitian yang dapat dilakukan ke perpustakaan untuk membaca beberapa buku-buku ilmiah dan tulisan-tulisanyang berhubungan dengan pembahasan yang akan dilakukan.

2. Metode analisa data

Adapun metode data yang digunakan adalah metode kualitatif merupakan metode yang dilakukan untuk mendapatkan informasi terkait melalui wawancara terhadap Bank Nagari Pusat dan menggunakan metode 
deskriptif, yaitu prosedur pemecahan masalah yang diselidiki dengan menggambarkan keadaan subjek atau objek dalam penelitian.

HASIL DAN PEMBAHASAN

Tabel 1

Laporan Keuangan Bank Nagari Pusat

Periode 2017-2019

\begin{tabular}{|l|c|c|c|}
\multicolumn{2}{c|}{} & \multicolumn{3}{c|}{ (Dalam Jutaan Rupiah) } \\
\cline { 2 - 4 } \multicolumn{1}{c|}{ Keterangan } & 2017 & 2018 & 2019 \\
\hline Kas & 35.064 .472 & 34.484 .141 & 38.571 .581 \\
\hline Modal Sendiri & 12.000 .000 & 12.000 .000 & 12.000 .000 \\
\hline Aktiva Lancar & 40.371 .464 & 50.190 .691 & 65.433 .596 \\
\hline Hutang Lancar & 19.558 .523 & 21.350 .536 & 23.630 .992 \\
\hline Surat Berharga & 1.023 .842 & 7.676 .916 & 11.367 .736 \\
\hline Total Hutang & 19.558 .523 & 21.350 .536 & 23.630 .992 \\
\hline Total Aktiva & 40.371 .464 & 50.190 .691 & 65.433 .596 \\
\hline Laba Bersih Setelah Pajak & 13.301 .124 & 16.344 .323 & 26.377 .107 \\
\hline
\end{tabular}

Sumber: OJK (Otoritas Jasa Keuangan)

Menurut (Haribowo, 2013) Rasio Keuangan dapat dibagi kedalam tiga bentuk umum yang sering dipergunakan yaitu : Rasio Likuiditas, Rasio Solvabilitas, dan Rasio Profitabilitas.

1. Rasio Likuiditas (Liquidity Ratio)

Likuiditas adalah kemampuan perusahaan dalam memenuhi Kewajiban jangka pendeknya. Pengertian lain adalah kemampuan seseorang atau perusahaan untuk memenuhi kewajiban atau hutang yang segera harus dibayar dengan harta lancarnya.

a. Current Ratio (Rasio Lancar)

Current Ratio adalah membandingkan antara total aktiva dengan kewajiban lancar. Menunjukkan sejauh mana aktiva lancar menutupi kewajiban-kewajiban lancarnya (Rakhmawati et al., 2017). Semakin besar perbandingan-perbandingan aktiva lancar dengan hutang lancar, semakin tinggi kemampuan perusahaan untuk menutupi kemampuan kewajiban jangka pendeknya. Apabila rasio lancar ini 100\% berarti aktiva lancar dapat menutupi semua hutang lancar.

Current Ratio dapat dihitung dengan rumus:

b. Cash Ratio (Rasio Kas)

$$
\text { Current Ratio }=\frac{\text { Aktiva Lancar }}{\text { Hutang Lancar }} \times 100 \%
$$

Merupakan rasio yang digunakan untuk mengukur kemampuan perusahaan dalam membayar kewajiban jangka pendek dengan kas yang tersedia dan yang disimpan di Bank.

Cash Ratio dapat dihitung dengan rumus: 
2. Rasio Solvabilitas

$$
\text { Cach Ratio }=\frac{\text { Kas }+ \text { Surat Berharga }}{\text { Hutang Lancar }} \times 100 \%
$$

Solvabilitas adalah menggambarkan kemampuan perusahaan dalam membayar kewajiban jangka panjang maupun kewajiban-kewajibannya yang apabila perusahaan dilikuidasi (Iryani, 2015). Rasio ini dapat dihitung dari pos-pos atau sifatnya jangka panjang seperti aktiva tetap utang jangka panjang. Adapun yang termasuk Rasio Solvabilitas adalah sebagai berikut :

a. Total Debt to Asset (Rasio Hutang terhadap Aktiva)

Rasio ini merupakan perbandingan antara total hutang (total debt) dengan total asset. Rasio hutang mengukur berapa persen aset perusahaan yang dibelanjai dengan hutang.

Rasio ini dapat dihitung dengan rumus yaitu:

$$
\text { Total Debt to Asset Ratio }=\frac{\text { Total Hutang }}{\text { Total Aktiva }} \times 100 \%
$$

b. Total Debt to Equity Ratio (Rasio Hutang terhadap Total Ekuitas)

Merupakan perbandingan total hutang dengan yang dimiliki perusahaan dengan modal sendiri (ekuitas). Artinya bagian dari setiap rupiah modal sendiri yang dijadikan jaminan untuk keseluruhan hutang perusahaan.

Rasio ini dapat dihitung dengan rumus yaitu:

3. Rasio Profitabilitas

$$
\text { Total Debt to Equity Ratio }=\frac{\text { Total Hutang }}{\text { Modal Sendiri }} \times 100 \%
$$

Rasio Profitabilitas adalah rasio yang menunjukkan kemampuan perusahaan untuk memperoleh keuntungan dari penggunaan modalnya. Semua rasio yang ada dalam profitabilitas dinyatakan dalam presentase (\%) serta jika terjadi peningkatan nilai rasio tiap tahunnya menandakan itu baik bagi perusahaan.

Adapun jenis rasio yang terdapat dalam rasio profitabilitas yaitu:

a. Return On Investmen (Rasio Pengembalian atas Aktiva)

Rasio ini mengukur pengembalian atas total aktiva setelah bunga dan pajak. Hasil pengembalian total aktiva atau total investasi menunjukkan kinerja management dalam menggunakan aktiva perusahaan untuk menghasilkan laba.

Rasio ini dapat dihitung dengan rumus:

b. Return On Equity (ROE)

$$
R O I=\frac{\text { Laba Bersih setelah Pajak }}{\text { Total Aktiva }} \times 100 \%
$$

Merupakan rasio yang digunakan untuk mengukur kemampuan dari modal sendiri untuk menghasilkan keuntungan bagi seluruh pemegang saham, baik saham biasa maupun saham prefern.

Rasio ini dapat dihitung dengan rumus:

$$
R O E=\frac{\text { Laba Bersih setelah Pajak }}{\text { Modal Sendiri }} \times 100 \%
$$


Kriteria rasio Likuiditas sesuai dengan Bank Indonesia No. 6/23/DPNP tahun 2009 sebagai berikut :

a. Current Ratio

\begin{tabular}{|c|c|}
\hline Standar & Kriteria \\
\hline$>100 \%$ & Sehat \\
\hline $80 \%-90 \%$ & Cukup Sehat \\
\hline $60 \%-70 \%$ & Kurang Sehat \\
\hline $40 \%-50 \%$ & Tidak Sehat \\
\hline $20 \%-30 \%$ & Sangat Tidak Sehat \\
\hline
\end{tabular}

b. Cash Ratio

\begin{tabular}{|c|c|}
\hline Standar & Kriteria \\
\hline$>100 \%$ & Sehat \\
\hline $80 \%-90 \%$ & Cukup Sehat \\
\hline $60 \%-70 \%$ & Kurang Sehat \\
\hline $40 \%-50 \%$ & Tidak Sehat \\
\hline $20 \%-30 \%$ & Sangat Tidak Sehat \\
\hline
\end{tabular}

Kriteria rasio Solvabilitas sesuai dengan Bank Indonesia N0. 6/23/DPNP tahun 2009 sebagai berikut :

a. Total Debt to Asset Ratios

\begin{tabular}{|c|c|}
\hline Standar & Kriteria \\
\hline$\geq 40 \%$ & Sehat \\
\hline $35 \%-40 \%$ & Cukup Sehat \\
\hline $30 \%-35 \%$ & Kurang Sehat \\
\hline $25 \%-30 \%$ & Tidak Sehat \\
\hline$<25 \%$ & Sangat Tidak Sehat \\
\hline
\end{tabular}

b. Total Debt to Equity Ratio

\begin{tabular}{|c|c|}
\hline Standar & Kriteria \\
\hline$>100 \%$ & Sehat \\
\hline $80 \%-90 \%$ & Cukup Sehat \\
\hline $60 \%-70 \%$ & Kurang Sehat \\
\hline $40 \%-50 \%$ & Tidak Sehat \\
\hline $20 \%-30 \%$ & Sangat Tidak Sehat \\
\hline
\end{tabular}

Kriteria rasio Profitabilitas sesuai dengan Bank Indonesia N0. 6/23/DPNP tahun 2009 sebagai berikut :

a. Return On Invesment

\begin{tabular}{|c|c|}
\hline Standar & Kriteria \\
\hline ROI $>0,3$ atau $30 \%$ & Sehat \\
\hline$<30 \%$ & Cukup Sehat \\
\hline$<15 \%$ & Kurang Sehat \\
\hline$<10 \%$ & Tidak Sehat \\
\hline ROI $<5 \%$ & Sangat Tidak Sehat \\
\hline
\end{tabular}


b. Return On Equity

\begin{tabular}{|c|c|}
\hline Standar & Kriteria \\
\hline$>100 \%$ & Sehat \\
\hline $80 \%-90 \%$ & Cukup Sehat \\
\hline $60 \%-70 \%$ & Kurang Sehat \\
\hline $40 \%-50 \%$ & Tidak Sehat \\
\hline $20 \%-30 \%$ & Sangat Tidak Sehat \\
\hline
\end{tabular}

Rasio likuiditas, solvabilitas, dan profitabilitas Bank Nagari Pusat dari tahun 2017 - 2019 dapat digambarkan sebagai berikut :

Tabel 3.1

Perhitungan Rasio Likuiditas, Solvabilitas dan Profitabilitas

Tahun 2017 - 2019

\begin{tabular}{|c|c|c|c|c|c|c|}
\hline \multirow{2}{*}{ Tahun } & \multicolumn{2}{|c|}{ Rasio Likuiditas } & \multicolumn{2}{c|}{ Rasio Solvabilitas } & \multicolumn{2}{c|}{ Rasio Profitabilitas } \\
\cline { 2 - 7 } & $\begin{array}{c}\text { Current } \\
\text { Ratio }\end{array}$ & $\begin{array}{c}\text { Cash } \\
\text { Ratio }\end{array}$ & TDAR & TDER & ROI & ROE \\
\hline 2017 & $206,41 \%$ & $184,50 \%$ & $48,44 \%$ & $162,98 \%$ & $32,90 \%$ & $110,84 \%$ \\
\hline 2018 & $235,07 \%$ & $197,47 \%$ & $42,53 \%$ & $177,92 \%$ & $32,56 \%$ & $136,20 \%$ \\
\hline 2019 & $276,89 \%$ & $211,32 \%$ & $36,11 \%$ & $196,92 \%$ & $40,31 \%$ & $219,80 \%$ \\
\hline
\end{tabular}

Menurut surat edaran Bank Indonesia No. 6/23/DPNP tahun 2009 bahwa current ratio ini nilainya sesuai surat edaran Bank Indonesia yaitu berada diatas nilai rata-rata sebesar 200\% dimana bank tersebut dikategorikan sehat.

Dari tabel 3.1 diatas perkembangan nilai current ratio dari tahun 2017 sampai 2018 mengalami peningkatan sebesar 13,90\% angka ini juga mengalami peningkatan pada tahun berikutnya menjadi $17,79 \%$. Hal ini menunjukkan bahwa bank mampu membayar hutang jangka pendeknya dengan menggunakan aktiva lancar yang dimiliki.

Menurut surat edaran Bank Indonesia No. 6/23/DPNP tahun 2009 bahwa pada rentan waktu 2017 sampai tahun 2018 cash ratio Bank Nagari berada diatas nilai rata-rata yaitu sebesar $100 \%$ dimana bank tersebut dikategorikan sehat.

Dilihat dari perkembangan nilai cash ratio dari tahun 2017 sampai 2018 mengalami peningkatan sebesar 7,02\% tetapi pada tahun 2018 sampai 2019 mengalami penurunan menjadi $7,01 \%$. Walaupun bank mengalami penurunan tetapi bank masih mampu untuk membayar kewajiban jangka pendek dengan kas yang tersedia.

Menurut surat edaran Bank Indonesia No. 6/23/DPNP tahun 2009 bahwa total debt to asset ratio (TDAR) ini nilainya sesuai surat edaran Bank Indonesia yaitu berada diatas nilai rata-rata sebesar $>40 \%$ dimana bank tersebut dikategorikan sehat.

Pada tabel 3.1 diatas perkembangan nilai total debt to asset ratio (TDAR) dari tahun 2017 sampai 2018 mengalami peningkatan sebesar 12,20\% akan tetapi pada tahun 2019 mengalami penurunan sebesar 36,11\% walaupun mengalami penurunan di tahun 2019 Bank Nagari masih di kategorikan sebagi bank yang cukup sehat menurut surat edaran Bank Indonesia No. 6/23/DPNP tahun 2009. Hal ini menunjukkan bahwa bank masih mampu membayar hutang jangka panjangnya maupun kewajiban-kewajibannya. 
Menurut surat edaran Bank Indonesia No. 6/23/DPNP tahun 2009 bahwa total debt to equity ratio (TDER) ini nilainya sesuai surat edaran Bank Indonesia yaitu berada diatas nilai rata-rata sebesar $100 \%$ dimana bank tersebut dikategorikan sehat.

Dilihat dari nilai total debt to equity ratio (TDER) dari tahun 2017 sampai 2018 mengalami peningkatan sebesar 9,16\% angka ini juga mengalami peningkatan pada tahun berikutnya sebesar $10,67 \%$. Hal ini menunjukkan bahwa bank mampu menjadikan setiap rupiah modal sendiri untuk keseluruhan hutang bank.

Menurut surat edaran Bank Indonesia No. 6/23/DPNP tahun 2009 bahwa return on investment (ROI) ini nilainya sesuai surat edaran Bank Indonesia yaitu berada diatas nilai rata-rata sebesar $>30 \%$ dimana bank tersebut dikategorikan sehat.

Dari tabel 3.1 diatas perkembangan nilai return on investment (ROI) dari tahun 2017 sampai 2018 mengalami peningkatan sebesar 1,03\% dan pada tahun 2018 sampai 2019 mengalami peningkatan yang cukup tinggi yaitu sebesar 23,80\%. Hal ini menunjukkan bahwa bank mampu menghasilkan laba bersih dengan menggunakan aktiva nya.

Menurut surat edaran Bank Indonesia No. 6/23/DPNP tahun 2009 bahwa return on equity (ROE) ini nilainya sesuai surat edaran Bank Indonesia yaitu berada diatas nilai rata-rata sebesar $100 \%$ dimana bank tersebut dikategorikan sehat.

Pada nilai return on equity (ROE) dari tahun 2017 sampai 2018 mengalami peningkatan sebesar 18,61\% dan pada tahun 2018 sampai 2019 mengalami peningkatan yang cukup tinggi yaitu sebesar $61,38 \%$. Hal ini menunjukkan bahwa bank mampu menghasilkan keuntungan dari modal sendiri untuk seluruh pemegang saham, baik saham biasa maupun saham prefern.

Bank Nagari bekerjasama dengan Dinas Perdagangan Kota Padang dalam pengambilan retribusi pasar melalui aplikasi non tunai atau e-retribusi. Program ini akan mulai diimplementasikan pada hari kamis tanggal 25 Juni 2020 di Pasar sebagai penunjang projek dan peningkatan produksi pasar yang selektif yang dipimpin oleh Kepala Bagian Dana dan Kepala Dinas Perdagangan Kota Padang. Dengan adanya kerjasama ini semua retribusi yang dipungut oleh Pemko Padang di Pasar maupun pasar lainnya diambil alih oleh Bank Nagari, Hal ini membuktikan bahwa Bank Nagari dipercaya oleh Pemerintah sebagai penyalur dana di pasar-pasar yang telah ditentukan. Dengan demikian pemerintah meminta analisis data dalam bentuk tingkat pengawasan apakah bank dalam kondisi sehat atau tidak, analisis tersebut dilakukan pada tabel 3.1 dengan tingkat rasio Likuiditas, Solvabilitas dan Profitabilitas. Analisis tersebut dilakukan pada periode tahun 2017 sampai tahun 2019 dan dinyatakan bahwa Bank Nagari berada dalam likuid atau sehat.

\section{SIMPULAN}

Berdasarkan perkembangan nilai kinerja keuangan pada Bank Nagari Pusat dari tahun 2017 sampai tahun 2019 terhadap rasio keuangan nya melalui analisis rasio keuangan yaitu rasio likuiditas, solvabilitas, dan profitabilitas maka 
dapat ditarik kesimpulan bahwa rasio likuiditas perusahaan dari tahun 2017 sampai tahun 2019 menunjukkan kinerja perusahaan cukup baik atau likuid karena nilai masing-masing rasio tiap tahun berada diatas $100 \%$ dan selalu meningkat dari tahun-tahun sebelumnya.

Rasio solvabilitas perusahaan tahun 2019 pada TDAR nilainya sebesar $36,11 \%$ swalaupun mengalami penurunan tetapi bank masih termasuk ke dalam kategori cukup sehat menurut surat edaran Bank Indonesia No. 6/23/DPNP tahun 2009 yang berarti bank masih mampu menutupi keseluruhan hutang. Hal ini menunjukkan bahwa secara keseluruhan rasio solvabilitas dari tahun 2017 sampai tahun 2019 telah menunjukkan kinerja perusahaan yang cukup baik, karena setiap tahun hutangnya mampu dibayar dari total aktiva maupun dari modal sendiri.

Rasio profitabilitas pada ROE ditahun 2019 mengalami kenaikan yang cukup tinggi sebesar 219,80\%. Dalam hal ini kinerja perusahaan dapat dikatakan baik karena perusahaan telah mampu menghasilkan laba dalam setiap periodenya.

\section{UCAPAN TERIMA KASIH}

Terimakasih penulis sampaikan kepada :

1. Kepada kedua Orang Tua yang selalu memberikan dukungan baik secara moril maupun materil.

2. Direktur AKBP beserta prodi AKBP yang telah memberikan kesempatan kepada penulis untuk melakukan penelitian ini.

3. Dosen pebimbing yang telah memberikan arahan dan bimbingan hingga tugas akhir ini bisa terselesaikan.

4. Pimpinan PT. BPR Jorong Kampung Tangah Cabang Padang yang telah mengizinkan penulis dalam memperoleh informasi beserta pengambilan data.

5. Semua pihak yang telah memberikan dukungan dan bantuannya dalam penyelesian tugas akhir ini

\section{DAFTAR PUSTAKA}

Albahi, M. (2015). Analisa Rasio Likuiditas, Rasio Rentabilitas, Rasio Solvabilitas Pada Kinerja Keuangan PT. Bank Sumut Cabang Pirngadi Medan. 1(2), 1-21.

Handayani, M., \& Marlius, D. (2017). Analisis Tingkat Kesehatan PT. BPR Batang Kapas. https://doi.org/10.31227/osf.io/bq48z

Haribowo, I. (2013). Analisis Perbandingan Pengaruh Kualitas Audit Likuiditas, Solvabilitas, Profitabilitas Terhadap Opini Audit Going Concern. X(3), 51-67.

Hutabarat, S. (2013). Pengaruh Rasio Likuiditas, Solvabilitas, Aktivitas, Profitabilitas Dan Rasio Pasar Terhadap Perubahan Laba. 53(9), 16891699. https://doi.org/10.1017/CBO9781107415324.004

Iryani, L. D. (2015). Analisis Rasio Likuiditas, Solvabilitas, Dan Profitabilitas Dalam Mendukung Pembiayaan Pada Pt Bank Danamon Indonesia, Tbk. 1(2), 32-40. https://doi.org/10.34204/jiafe.v1i2.514 
Marlius, D., \& Pebriyana, S. (2020). Analisis Rasio Profitabilitas Pada Pt. Bank Pembangunan Daerah Sumatera Barat Cabang Utama Padang. https://doi.org/10.31219/osf.io/7gnd5

Marlius, D., \& Mutia, M. (2020). Analisis Rasio Profitabilitas Pada Pt. Bank Pembangunan Daerah Sumatera Barat Cabang Pembantu Rsup Dr. M. Djamil Padang. https://doi.org/10.31219/osf.io/9nrc7

Nidya Afrinda. (2013). Analisis Pengaruh Likuiditas Dan Solvabilitas Terhadap Profitabilitas Pda Perusahaan Makanan Dan Minuman Yang Terdaftar Di BEI. 1-23.

Putri, D. M., \& Marlius, D. (2020). Analisis Rasio Profitabilitas Pada Pt. Bank Perkreditan Rakyat Lugas Dana Mandiri Padang. https://doi.org/10.31219/osf.io/kaw2e

Putri, Y. A., \& Marlius, D. (2018). Analisis Tingkat Kesehatan Bank Pada PT. Bank Perkreditan Rakyat (BPR) Jorong Kampuang Tangah Pariaman Cabang Padang. https://doi.org/10.31227/osf.io/r98pv

Rakhmawati, A. N., Lestari, T., \& Rosyafah, S. (2017). Analisis Rasio Likuiditas, Solvabilitas dan Profitabilitas guna mengukur Kinerja Keuangan PT. Vepo Indah Pratama gresik. 3(3), 94-107s.

Sepang, F. V., Manoppo, W. S., \& Mangindaan, J. V. (2019). Analisis Kinerja Keuangan Dengan Menggunakan Rasio Likuiditas, Solvabilitas Dan Profitabilitas Pada PT. Bank BRI (Persero), Tbk. 17(01), 18-31. https://doi.org/10.35129/simak.v17i01.64

Utomo, A. P. (2008). Pengaruh Non Performing Loan Terhadap Kinerja Keuangan Bank Berdasarkan Rasio Likuiditas, Rasio Solvabilitas, Dan Rasio Profitabilitas Pada PT. Bank Mandiri (Persero), Tbk.

Vernida, M., \& Marlius, D. (2020). Analisis Rasio Profitabilitas Pada Pt. Bank Perkreditan Rakyat Cempaka Mitra Nagari Padang. https://doi.org/10.31219/osf.io/6usfx

Yusra, I. (2016). Kemampuan Rasio Likuiditas Dan Solvabilitas Dalam Memprediksi Laba Perusahaan. 1(1), 33-42. https://doi.org/10.22216/jbe.v1i1.878 